\title{
The Influence of Asmaul Husna Dhikr on Adolescent Emotional Intelligence
}

\author{
Evi Ni'matuzzakiyah ${ }^{1 *}$ \\ ${ }^{1}$ STIKES Surya Global Yogyakarta \\ *Corespending author: ${ }^{1}$ evi_zakiyah@stikessuryaglobal.ac.id
}

\begin{abstract}
Today, the reality of the condition of Indonesian society shows that there are symptoms of deterioration caused by a shift in the noble values of the nation. Rampant juvenile delinquency and violation of norms, emotional intelligence is a basic condition for using intellectual intelligence effectively. Asmaul Husna's reading habit is one of the character education being pursued by the Surya Global Yogyakarta College of Health Sciences. Students are also trained and educated to develop their skills and mentality in a positive direction so that these educational institutions can produce superior and Islamic output, which is not only rely on theory in learning, but also experience in the field in facing the flow of globalization. The gap between the theory and practice of Asmaul's reading habits Husna with the level of students 'emotional intelligence, it is necessary to revisit considering the effect of Asmaul Husna's reading habit on students' emotional intelligence is not known. The research design is quantitative using the Emotional Intelligence Scale. The research was conducted at the College of Public Health Sciences. The research subjects were 65 adolescents, they were asked to fill in the pretest before Asmaul Husna dhikr intervention was carried out, and after going through the dhikr process for ten weeks the research subjects were asked to fill in the posttest. Pretest and posttest data were analyzed through the Wilcoxon test using SPSS 16. Based on the above results, it is known that the significance of 0.031 is smaller than 0.05 , so it can be concluded that "Ha is accepted" This means that there is a difference in emotional intelligence between before and after Asmaul Husna's dhikr, so it can also be concluded that "There is an influence of Asmaul Husna's dhikr on adolescent emotional intelligence.
\end{abstract}

Keywords: Asmaul Husna; Adolescent; Emotional Intelligence. 


\section{Introduction}

Today, the condition reality of Indonesian society shows shows that there are symptoms of deterioration caused by a shift in the noble values of the nation. The rise of juvenile delinquency and violations of norms such as religious norms by students is caused by a lack of appreciation and implementation of the values of Islamic education and the unstable emotional level of students. It is true that in their teens like those who are currently studying in college, most of them are at a point of instability. Adolescence is a time when there are various psychological and physical changes. At this time, adolescents experience emotional turmoil and mental stress so that they easily deviate from the rules and social norms that apply in society.

This is where the role of education becomes very urgent in preventing and overcoming various educational problems. One of the main goals of the Islamic education process is to foster the emotional aspects of students, considering that one of the goals of Islamic education is to create a whole human being so that he can live a good life and be guided by Islamic values. In order for this goal to be achieved, there needs to be an effort to overcome the negative impacts of modernity, one of which is the practice of religious teachings that can be routinized in everyday life as a character building process.

According to Golemen, the learning process is not only aimed at pursuing the results of academic achievement, but also aims at attaining attitudinal skills and forming a person to have a person with superior and Islamic character. ${ }^{1}$ So far, people often think that intellectual intelligence (IQ) is seen as a barometer to predict a person's success. However, according to Shapiro after being researched that the highest intellectual intelligence only contributes about $20 \%$ to life success. ${ }^{2}$

Therefore, it is not enough just intellectual intelligence (IQ) and spiritual intelligence (SQ) which are used as benchmarks for achieving success in the world and the hereafter, emotional intelligence (EQ) is also needed to be a balance in dealing with increasingly complex life problems. Emotional intelligence provides awareness of one's own feelings as well as the feelings of others, with emotional intelligence can also give a person a sense of love, motivation, empathy and the ability to respond to sadness or joy appropriately. Goleman said that emotional intelligence is a basic requirement for using intellectual intelligence effectively.

\footnotetext{
Daniel Goleman, "Kecerdasan Emosional, Terj," T. Hermaya, Jakarta: Gramedia Pustaka Utama, 1996.

2 L E Shapiro, "Mengajarkan Emotional Intelligensi Pada Anak Jakarta: Gramedia Pustaka Utama," 2003.
} 
Zohar and Marshall argued that several formal educational institutions such as universities have taken steps in providing alternative solutions to overcome educational problems ${ }^{3}$, one of which is the Yogyakarta Global School of Health Sciences. This educational institution has turned the theory of lessons, especially Islamic Religious Education into action in the form of daily practice, namely reading Asmaul Husna.

Asmaul Husna's reading habit is a character education pursued by the Surya Global Yogyakarta College of Health Sciences as a form of prayer in preparation for studying so that students are expected to find it easier in the process of digesting knowledge. Students are also trained and educated to develop their skills and mentality in a positive direction so that these educational institutions can produce superior and Islamic output, which do not only rely on theory in their learning but also experience in their fields in facing the current of globalization .With this, it can be seen that the Surya Global Yogyakart College of Health is very concerned about the quality of its resources. Ideally, if the reading level of Asmaul Husna Mahasiwa is high, then the level of emotional intelligence is also high.

The gap between the theory and practice of Asmaul Husna's reading habits with the level of students 'emotional intelligence, it is necessary to revisit considering the effect of Asmaul Husna's reading habit on students' emotional intelligence is not known. Based on this background, researchers are interested and feel the need to examine in depth the influence of Asmaul Husna dhikr on emotional intelligence.

\section{Literature Review}

Research conducted by Fathonah on the relationship between the habituation of Asmaul Husna and the spiritual intelligence of class XI students of MAN $1 \mathrm{Bantul}^{4}$, the research design is quantitative using scales, documentation, and interviews. Data analysis through product moment correlation analysis and descriptive analysis.

Research by Khasanah on the effect of doing Asmul Husna dhikr on anxiety in facing the national exam for children at the Darussalam Orphanage Mranggen

3 Danah Zohar and Ian Marshall, "SQ: Kecerdasan Spiritual, Terj," Rahmani Astuti, Abmad Najib Burbani, Abmad Baiquni, Cet. XI Bandung: Mizan, 2007.

4 Nur Fathonah, "Hubungan Antara Pembiasaan Asmaul Husna Dengan Kecerdasan Spiritual Siswa Kelas XI MAN 1 Bantul Yogyakarta,” Universitas Islam Negeri Sunan Kalijaga (n.d.). 
Demak, the design of this study was an experiment using pretest-posstest from the experimental group and the control group. ${ }^{5}$

Research by Khoirunnisa on the relationship between Asmaul Husna's reading habits and emotional intelligence of class XI students of Madrasah Aliyah Nurul Ummah Yogyakarta, the research design used a population research model and data collection was carried out using a questionnaire and scale method. Descriptive analysis and correlation were used to analyze the data. ${ }^{6}$

Research conducted by Febriani on the role of Asmaul Husna reading in learning figh at Madrasah Aliyah Negeri Sidoarjo. This research uses a qualitative approach and the type of research is descriptive, while the data collection techniques are through observation, interviews, and documentation. ${ }^{7}$

\section{Methods}

The research design was quantitative with a research instrument in the form of an Emotional Intelligence Scale. This study consisted of two variables, namely dhikr Asmaul Husna as the independent variable and Emotional Intelligence as the dependent variable. The research was conducted at the College of Public Health Sciences. The research process was carried out from March 20, 2018 to June 27, 2018.

Characteristics of research subjects are late adolescents aged 19 to 21 years $^{8}$, they have lived / resided / studied in Islamic boarding schools, students of the Public Health Study Program of the Surya Global School of Health Sciences Yogyakarta

On March 20, 2018 students were asked to fill in the Emotional Intelligence Scale as a pretest before the Asmaul Husna dhikr intervention was carried out. Furthermore, Asmaul Husna dhikr is performed every week with a duration of 15 minutes for ten weeks, in the following week students are asked to fill in the Emotional Intelligence Scale for the second time as a posttest.

5 Ismatun Khasanah, "Pengaruh Melakukan Dzikir Asmaul Husna Terhadap Kecemasan Dalam Menghadapi Ujian Nasional Anak Panti Asuhan Darussalam Mranggen Demak” (UIN Walisongo, 2015).

6 Lili Khoirunnisa, "Hubungan Antara Kebiasaan Membaca Asmaul Husna Dengan Kecerdasan Emosional Siswa Kelas XI MA Nurul Ummah Yogyakarta," Jurnal Pendidikan Agama Islam 14, no. 1 (2017): 51-68.

7 Fitri Febriyani, "Peran Pembacaan Asmaul Husna Dalam Pembelajaran Fiqih Di Madrasah Aliyah Negeri Sidoarjo" (UIN Sunan Ampel Surabaya, 2018).

8 John W. Santrock, Psikologi Remaja (Jakarta: Erlangga, 2007). 
Based on the results of the pretest and posttest, the results of the normality test showed that the data were not normally distributed. So that the researchers processed the final data using a non-parametric test, namely the Wilcoxon Signed-Rank Test ${ }^{9}$ using the SPSS 16.0 for Windows program.

\section{Result and Discussion}

The research was carried out to obtain real data, then it would be analyzed statistically to test the research hypothesis. The first step, from the pretest and posttest data, the data normality test was carried out, because the data were not normally distributed, the researchers used the Wilcoxon test to find out the difference between before and after Asmaul Husna's dhikr intervention. The Wilcoxon test results can be seen in the following table.

Table 1. Results of the Pretest and Posttest using Wilcoxon test

\begin{tabular}{llll}
\hline Data & N & Mean Rank & Sum of Rank \\
\hline Pre test (positive rank) & 41 & 34,20 & 1402 \\
Posttest (negative rank) & 24 & 30,96 & 743 \\
Ties & 0 & & \\
Total & 65 & & \\
\hline
\end{tabular}

Based on the table of statistical results through the Wilcoxon test using SPSS 16 above, the negative ranks or the negative difference between the pretest and posttest results of adolescent emotional intelligence before and after Asmaul Husna's dhikr is 24 , this shows that there are 24 people who experience a decrease in postest scores, which means that the pretest score is higher than the posttest or it means that there is a decrease in emotional intelligence after the intervening process of Asmaul Husna's dhikr as many as 24 people with an average value of 30.96 , and the sum value of 743 .

Positive ranks or the positive difference between the results of the pretest and posttest on the Emotional Intelligence Scale of adolescents after Asmaul Husna's dhikr, there are 41 out of 65 people, meaning that 41 people experience an increase in emotional intelligence with an average value of 34.20 , while the sum or sum rank is equal to 1402 .

9 Allan G. Bluman, "Elementary Statistic a Step by Step Approach," in Eighth Edition (New York: McGraw-Hill, 2012). 
Table 2.t-test

\begin{tabular}{ll}
\hline Uji t & Pretest \\
& Postest \\
\hline$Z$ & $-2,154$ \\
Asymp. Sig. (2-tailed) & 0,031 \\
\hline
\end{tabular}

Based on the above results, it is known that the significance of 0.031 is smaller than 0.05 , so it can be concluded that "Ha is accepted" This means that there is a difference in emotional intelligence between before and after Asmaul Husna's dhikr, so it can also be concluded that "There is an influence of Asmaul Husna's dhikr on emotional intelligence. teenager.

A similar research was conducted by Khoirunnisa ${ }^{10}$, a student majoring in Islamic Education, Faculty of Tarbiyah and Teacher Training, UIN Sunan Kalijaga Yogyakarta with the title "The relationship between reading Asmaul Husna and the Emotional Intelligence of Grade XI students of Madrasah Aliyah Nurul Ummah Yogyakarta". This research is a quantitative study with an educational psychology approach. This study uses a population research model with 34 students as the subject. The results showed that the relationship between Asmaul Husna's reading habits and the emotional violence of class XI students of Madrasah Aliyah Nurul Ummah Yogyakarta was a significant positive, this is evidenced by the results of statistical data analysis of product momet of 0.614 and if interpreted by a table of values, it is included in the category "high / strong.

In addition, Fathonah ${ }^{11}$ from the Islamic University of Sunan Kalijaga in his research entitled The Relationship Between Asmaul Husna's Habituation and the Spiritual Intelligence of Class XI Students of MAN 1 Bantul Yogyakarta Based on the analysis carried out, the product correlation coefficient value of $\mathrm{rxy}$ moment is 0.524 , with a $\mathrm{p}$ value. $=0.000<0.05$, it is significant. Then the alternative hypothesis (HA) is accepted, and the null hypothesis (HO) is rejected. This shows that there is a significant positive relationship between the habituation of Asmaul Husna and spiritual intelligence. This means that the higher the habituation of Asmaul Husna, the higher the spiritual intelligence,

10 Khoirunnisa, "Hubungan Antara Kebiasaan Membaca Asmaul Husna Dengan Kecerdasan Emosional Siswa Kelas XI MA Nurul Ummah Yogyakarta."

11 Fathonah, "Hubungan Antara Pembiasaan Asmaul Husna Dengan Kecerdasan Spiritual Siswa Kelas XI MAN 1 Bantul Yogyakarta.” 
and vice versa. 0.524 then obtained $\mathrm{R} 2(0.5242)=0.27$ with a percentage of $27 \%$. This means that the contribution of Asmaul Husna habituation to spiritual intelligence is $27 \%$, so there are still $73 \%$.

According Febriani ${ }^{12}$ from the Islamic University of Sunan Ampel in her research entitled The Role of Asmaul Husna Reading in Islamic Fiqh Learning at the State Islamic School of Sidoarjo stated that the application of Asmaul Husna reading in learning fiqh at Madrasah Aliyah Negeri Sidoarjo has been said to be good, because the teaching and learning process at the school has implemented Asmaul Husna readings at the beginning of each lesson. And the role of the habit of reading Asmaul Husna in learning fiqh is said to be effective because it can foster student motivation and improve students' polite attitudes.

One of the limitations of this study is the small sample size. Although the researcher attains sufficient strength for quantitative analysis, these findings do not represent how all students will feel and gain well-being with the dhikr intervention. Limited intervention time and results. In this study, the researcher also relied on self-reports from the study subjects, potentially creating biased responses.

\section{Conclussion}

The results of this study can be concluded that there is an influence of Asmaul Husna's dhikr on adolescent emotional intelligence, this is in line with the results of the money research conducted by ${ }^{13}$ who found that the relationship between Asmaul Husna's reading habits and the emotional violence of class XI students of Madrasah Aliyah Nurul Ummah Yogyakarta is a significant positive, with the results of product momet statistical data analysis interpreted to be in the category of "high/ strong."

\section{Acknowledgement}

Asmaul Husna Institute and Public Health of STIKES Surya Global Yogyakarta who have supported this research.

\footnotetext{
12 Fitri Febriani, "Peran Pembacaan Asmaul Husna Dalam Pembelajaran Fiqih Di Madrasah Aliyah Negeri Sidoarjo" (iUniversitas Islam Sunan Ampel, 2018).

13 Khoirunnisa (2016)
} 


\section{Reference}

Bluman, Allan G. "Elementary Statistic a Step by Step Approach." In Eighth Edition. New York: McGraw-Hill, 2012.

Fathonah, Nur. "Hubungan Antara Pembiasaan Asmaul Husna Dengan Kecerdasan Spiritual Siswa Kelas XI MAN 1 Bantul Yogyakarta." Universitas Islam Negeri Sunan Kalijaga, n.d.

Febriani, Fitri. "Peran Pembacaan Asmaul Husna Dalam Pembelajaran Fiqih Di Madrasah Aliyah Negeri Sidoarjo."iUniversitas Islam Sunan Ampel, 2018.

Febriyani, Fitri. "Peran Pembacaan Asmaul Husna Dalam Pembelajaran Fiqih Di Madrasah Aliyah Negeri Sidoarjo.”UIN Sunan Ampel Surabaya, 2018. Goleman, Daniel. "Kecerdasan Emosional, Terj." T. Hermaya, Jakarta: Gramedia Pustaka Utama, 1996.

Khasanah, Ismatun. "Pengaruh Melakukan Dzikir Asmaul Husna Terhadap Kecemasan Dalam Menghadapi Ujian Nasional Anak Panti Asuhan Darussalam Mranggen Demak.”UIN Walisongo, 2015.

Khoirunnisa, Lili. "Hubungan Antara Kebiasaan Membaca Asmaul Husna Dengan Kecerdasan Emosional Siswa Kelas XI MA Nurul Ummah Yogyakarta." Jurnal Pendidikan Agama Islam 14, no. 1 (2017): 51-68.

Khoirunnisa, Lili. "Hubungan Antara Membaca Asmaul Husna Dengan Kecerdasan Emosional Siswa Kelas XI Madrasah Aliyah Nurul Ummah Yogyakarta." Universitas Islam Negeri Sunan Kalijaga, 2016.

Santrock, John W. Psikologi Remaja. Jakarta: Erlangga, 2007.

Shapiro, L E."Mengajarkan Emotional Intelligensi Pada Anak Jakarta: Gramedia Pustaka Utama," 2003.

Zohar, Danah, and Ian Marshall. "SQ: Kecerdasan Spiritual, Terj." Rahmani Astuti, Ahmad Najib Burbani, Ahmad Baiquni, Cet. XI Bandung: Mizan, 2007. 